\title{
Entrepreneurial Orientation, Economic Factors and Performance of Selected Quoted Consumer Goods Manufacturing Companies in Nigeria: A Combined Effect
}

\author{
Babalola, Edward, A. $\mathrm{PhD}^{1} \quad$ Alase, Peter O. $\mathrm{PhD}^{2 *}$. Okusanya, A. O. PhD. ${ }^{3}$ \\ 1. Reader, Dept.of Management and Entrepreneurial Studies, Afe Babalola University, Ado-Ekiti \\ 2. Lecturer, Dept. of Management and Entrepreneurial Studies, Afe Babalola University, Ado-Ekiti \\ 3.Lecturer, Dept. of Business Education, Tai Solarin University of Education, Ijagun, Ijebu-Ode
}

\begin{abstract}
Performance does take central position in terms of business considering its role in assisting organisations to accomplishing goals and achieving successes. Consumer goods manufacturing industry in Nigeria are experiencing decline in performance these days due to poor entrepreneurial orientation and poor management of economic policies. This study examined entrepreneurial orientation, economic factors and performance of selected quoted consumer goods companies in Nigeria. Cross sectional survey design was employed and the population of the study was 1,551 of twelve (12) quoted consumer goods manufacturing companies in Nigeria. A structured questionnaire was used for data collection. The Cronbach's alpha ranges between 0.721 and 0.892 . The response rate was $90.5 \%$. Data were analyzed using descriptive and inferential statistics. The results revealed that entrepreneurial orientation $(\beta=0.420, \mathrm{t}=7.288, \mathrm{p}=0.000)$ and economic factors $(\beta=0.671, \mathrm{t}=11.098, \mathrm{p}=0.000)$ have positive and significant effects on performance of the selected quoted consumer goods companies in Nigeria. This implies that entrepreneurial orientation and economic factor are significant predictors of performance of selected quoted consumer goods companies in the study area. The study concluded that entrepreneurial orientation and economic factors had significant effects on performance of selected consumer goods companies in Nigeria and recommended that managers of selected consumer goods companies should be strategic and proactive enough to improve on performance of consumer goods manufacturing companies in Nigeria.
\end{abstract}

Keywords: Entrepreneurial orientation, Economic factors, Consumer goods companies, Nigeria.

DOI: $10.7176 / \mathrm{EJBM} / 13-22-03$

Publication date: November $30^{\text {th }} 2021$

\subsection{Introduction}

Manufacturing companies, most especially, consumer goods manufacturing industry around the globe are experiencing continuous challenges of maintaining stable performance indicators across different years of operations due to their inability to stem difficulties arising from the consequences of their inability to incorporate entrepreneurial orientation techniques and manage unstable economic policies indicators and ultimately resulting in decline in performance. This trend has captured the interests of scholars and professionals in strategic and entrepreneurship management to investigate the causes of unfavourable volatility and deterioration in consumer goods industry performance indicators. Deloitte Report (2020) showed that the deterioration in overall performance of consumer goods firms is so common all over the world including developed economies. In emerging economies like China, Singapore, and Malaysia, Deloitte Report (2020) reported that consumer goods companies like food and beverages companies account for decline in profitability, low market share due to global competition and open market policies in China and Singapore.

Like other developing regions, Nigeria consumer goods manufacturing industry has long been associated with substantial gaps in port, road, power infrastructure, poor supply network, high cost of manufacturing processes, input and output; not to mention its notoriously high levels of corruption and bureaucratic restrictions, which increase the cost of distribution and investment, thus cause the rundown of performance indicators such as profitability, market share, sales growth, competitive advantage and productivity in the Nigeria consumer goods manufacturing industry (Manufacturing Association of Nigeria (MAN), 2019). Ojeleye, Opusunju, and Abdullahi (2020) emphasized that part of the factor hindering growth and continuous performance in Nigeria consumer goods manufacturing industry relates to poor quality and non-availability of inputs in the local market, such as raw materials and equipment as well as limited size of the domestic market for manufactured products. The consumer goods manufacturing companies in Nigeria are yet to fully apply corporate entrepreneurial orientation techniques in managing unstable economic policies like importation policy, exchange and inflation rate, infrastructural facility and interest rate so as to achieve profitability, market share, sales growth, competitive advantage and productivityfirm performance (Egbunike \& Okerekeoti, 2018).

However, Adegbuyi, Oladele, Iyiola, Adegbuyi, Ogunnaike, Ibidunni and Fadeyi (2018) and Olubiyi et al. (2019) pointed that most of manufacturing companies in Nigeria do not strategically employ entrepreneurial orientation measure in managing challenges of unstable economic policies, thus reduce profitability, market share, 
sales growth, competitive advantage and productivity. It is based on these aforestressed negative developments and background challenges that this study examined the effect of entrepreneurial orientation (innovativeness, competitive aggressiveness, proactiveness, risk-taking, planning flexibility) on performance of selected quoted consumer goods manufacturing companies in Nigeria.

\subsection{Literature Review \\ Conceptual Framework \\ Entrepreneurial orientation}

Mwangi and Ngugi (2014) defined entrepreneurial orientation as the process and decision making activities used by entrepreneurs that lead to entry and support of business activities with strategy- making processes that provide organizations with a basis for entrepreneurial decisions and actions in order to achieve firm performance. Etim, Adabu, and Ogar (2017) view entrepreneurial orientation as a set of decision-making styles, processes, practices, rules, and norms according to which a firm makes decisions to enhance its innovativeness, pro-activeness and risk taking propensity. Omisakin, Nakhid, Littrell, and Verbitsky (2016) also conceptualized entrepreneurial orientation as the willingness of an entrepreneur to innovate, search for risks, take self-directed actions, and be more proactive and aggressive than competitors towards new market place opportunities so as to gain market share. Many scholars agree that EO is a combination of innovativeness, proactiveness, and risk taking (Ketchen \& Short 2012; Okangi, 2019).

Okangi (2019) further stated that the feature of entrepreneurial orientation is building an entrepreneurial orientation can be valuable to organizations and individuals alike in identifying and seizing new opportunities. Entrepreneurial orientation features are five dimensions: (1) autonomy, (2) competitive aggressiveness, (3) innovativeness, (4) proactiveness, and (5) risk taking. The advantages of entrepreneurial orientation are that entrepreneurial orientation is an intangible firm resource that creates competitive advantage and eventually promotes firm performance while the disadvantages are that wrongly application and employment of entrepreneurial orientation could adversely affect firm objectives, goals and overall performance (Okangi, 2019).

\section{Innovativeness}

Kiveu, Namusonge, and Muathe (2019) defines innovativeness as the introduction of a product which is new to consumers or with higher quality than existing products, new methods of production, the opening of new markets, the use of new sources of supply and new forms of competition, that lead to the restructuring of an industry. Mkalama, Ndemo, and Maalu (2018) defined innovativeness as the generation and implementation of new or improved processes, products/services, production methods aimed at increasing the competitiveness of an enterprise. OECD (2018) defined innovativeness as the implementation of a new or significantly improved product (good or service), or process, a new marketing method, or a new organisational method in business practices, workplace organisation or external relations (OECD, 2018).

Innovativeness is one of the key features of entrepreneurial behaviour linked to manufacturing companies (Ejdys, 2016). It is considered a dominant factor in firm competitiveness and the single most important factor in enhancing and sustaining competitiveness (Ejdys, 2016). Innovativeness is a key practice underpinning the survival and competitiveness of firms in a competitive globalised environment (Sheu, 2007). Within the business context, innovation is considered the basis of strategic change through which firms can gain and sustain competitive advantage (Lin \& Chen, 2007).

Kiveu, Namusonge and Muathe (2019) further stated that the features of innovativeness include adaptations, refinement, enhancements or line extensions; this is the most common features of innovativeness in many organisations Kiveu et al. (2019) stated that the advantages of innovativeness increase global competitive advantage, shortened product lifecycles and ease of imitation make it necessary for firms to innovate to sustain competitiveness (Hamid \& Tasmin, 2013). Hence pressure on all businesses to continually innovate by developing and launching new products and services is greater than ever (Wales, 2016). Innovativeness has thus become central to firm strategies and policies in the pursuit of firm competitiveness.

\section{Competitive Aggressiveness}

Linyiru and Ketyenya (2017) defined competitive aggressiveness as a strong struggle to overcome the competitors; it is characterized by a combative attitude or aggressive response, which seeks a better positioning in the market or defeat threats. Competitive aggressiveness, which has a relation with the organization's propensity, intensely and directly challenges its competitors reaching better market position, seeking to overcome competitors ( $\mathrm{Li}$, Huang \&Tasai 2010). Aigboje (2018) view competitive aggressiveness as firm's propensity to intensively challenge its competitors to improve its market position and outperform industry rivals in a marketplace. Competitively aggressive firms are those who pay close attention to their competitors' actions and initiate a series of their own. In other words, they prefer to invest in competitive actions such as product launches, marketing campaigns and price competition more frequently than others. It is characterized as the speed and number of 
competitive actions taken by a firm in comparison to the firm's direct rivals (Muhonen, 2017).

\section{Proactiveness}

Kurgat, Weru and Wata (2019) defined proactiveness is an attempts to discover future opportunities, even when these opportunities may be somewhat unrelated to existing operations. Proactiveness is achievement oriented, emphasizing initiatives taking, anticipating, creating change, and predicting evolution towards a critical situation and early preparation prior to the occurrence of an impeding uncertainty of risk (Hernández-Sánchez, Cardella, \& Sánchez-García, 2020). Proactiveness as a dimension of entrepreneurial orientation is an opportunity seeking and forward-looking perspective that involves acting in anticipation of future demand and trends, and thereafter capitalizing on these opportunities to gain benefit (Kropp, Lindsay \& Shoham, 2008). A strong proactive behavior gives SMEs the ability to anticipate needs in the market place and the capability to anticipate competitor's needs (Eggers, Kraus, Hughes, Laraway, \& Snycerski, 2013).

Proactiveness refers to a process that aims at anticipating and acting on future opportunities in terms of products, technologies and markets (Schillo, 2011) rather than reacting to events after they unfold (Ketchen \& Short, 2012). Proactiveness aims at introducing new products ahead of competitors, strategically eliminating operations that are in the declining stages of the business life cycle (Bass, 2008). Proactiveness shows how firms relate to market opportunities by seizing the initiative in the market place (Yang, 2012). Proactive firms have the desire to be pioneers (Reijonen, Tammi, \& Saastamoinen, 2014) by acting in advance and capitalizing on emerging opportunities (Ketchen \& Short 2012).

\section{Planning Flexibility}

Planning flexibility implies being capability of multiple responses to an organisation internal and external environment (Fink \& Benz, 2019). Jonsson (2007) stated that flexibility means that organisation can 'hire and fire' its employee at will due to weak labour-market regulations. Flexibility can also be seen as the degree which an organisation is adaptable to administrative relations and the authority that are rested in situational expertise (Adonsi, 2003). Kozjek and Ferjan (2015) used functional flexibility, numerical flexibility, external flexibility, and internal flexibility organization flexibilty to describe organization flexibility. Goodwin (2012) sees numerical flexibility as the capability of organizations and employers to regulate the number of its employees. Wachsen and Blind (2011) see numerical flexibility as external and internal numerical flexibility. Wachsen and Blind (2011) stated that external flexibility can be regarded as the ability of an organization to modify the number of workers to the activities in the organisation through the use of diverse means of employment.

\section{Risk Taking}

Risk Taking refers to a firm's tendency to engage and the willingness to commit significant resources to opportunities with uncertain outcomes (Bran \& Vaidis, 2019). Risk taking ability helps firms to engage in bold rather than cautious actions (Ketchen \& Short, 2012). Risk taking was acting by entering unfamiliar region, committing large sum of money and utilizing resources for conducting business in an environment replete with ambiguity (Javad et al., 2015). According to Okunbanjo, Adewale, and Akinsulire (2017) risk taking embodies taking brave steps, measures and commitment of financial and non-financial resources by gambling into an unknown business area.

Adisa, Adeoye, and Okunbanjo (2016) opined that risk-taking was all about taking bold actions by venturing into the unknown, borrowing large, and/or committing significant resources to ventures in undefined regions. According to Taylor (2013), Keh, Nguyen and Ng (2007) and Wiklund and Shepherd (2005), risk taking refers to an inclination of an individual, group, or organisation to take daring steps such as entering unknown new markets, committing a large portion of the firm's resources to undertakings with uncertain outcomes and/or borrowing heavily.

\section{Economic Factors}

Obeng-Krampah (2018) defined economic factors as the uncontrollable external factors that affect firm performance. Economic factors are forces surrounding a firm that have the potential to affect the way it operates (Davis \& Powell, 2012). The Institute of Chartered Accountants (ICAN) (2017) view economic factors as a set of factors or conditions that are external to the firm but which can influence the operations of the firm. Fosu, Bondzie, and Okyere (2014), defined economic factors as those conditions and forces which are external to the firm and are beyond the individual business unit, but they all operate within it. Economic conditions can affect future performance of firms and so should be included in predicting firm performance. But organizations should be wary of this since the importance of economic factors may vary from industry to industry and may not generally anticipate future performance for specific firms (Fuso et al., 2014). Moheddin (2018) stated that economic factors are one of the major factors that affect firm performance. Obeng-Krampah (2018) stated that the features of economic factors are exchange rates, inflation rates, interest rates and gross domestic product while the firm 
characteristics included working capital, size of firm and financial leverage.

Nyaruirumugure, Simiyu and Bunde (2017) view macroeconomic factors are economic factors that signal the current trends in the economy. For policy makers to manage the economy, they must study and understand these variables. Macroeconomic variables and policies are the same in all economies but the difference occurs in how they are applied in different countries. The major macroeconomic variables in economics are consumer price index, Money supply, interest rates, balance of payments, trade balance, unemployment, exchange rate, foreign direct investment, foreign aid among others.

\section{Importation Policy}

Oloyede and Essi (2017) defined an importation policy as policy on goods brought into a jurisdiction, especially across a national border, from an external source. An import in the receiving country is an export from the sending country (Moshen, 2013). Bakari and Mabrouki (2017) stated that as for import, it is generally reflected the weakness of the state in achieving its needs itself and makes them dependent and at the mercy of foreign countries. Imports unlike exports lead to the exit of the local currency and weaken the trade balance, thus weakening economic and firm growth especially manufacturing sector. Kartikasari (2017) view import policy as the activity of entering goods into the customs area. Literally, imports can be interpreted as the activities of entering goods from foreign country into the customs territory of our country (Susilo, 2008).

Kartikasari (2017) stated that the advantages of importation policy are that importation policy contribute to establishing and expand industrial sectors. Because new technology works as influencing factors to introduce the new industry. On the other side, some import goods especially the technology and machinery goods which improve the productivity of the economy. Therefore, this may help to improve the economic growth. Amiti and Konings (2007) mention that, when the economy has an access on high-quality intermediate goods at a cheaper price from the foreign market, it is better to import from a foreign country that will improve the quality of life. On the other hand, import medical goods which extend the life expectancy of the country. As a result, more workforces can able to work and it increases the output which finally improves the gross domestic product growth. Kartikasari (2017) further stated that demerit of importation policy are foreign goods are substituting the domestic goods' markets, so the domestic industries are eliminated, trade deficit will cause the currency devaluation, increase inflation and the importing of important industries will lose the influence by importing country.

\section{Inflation Rate}

Moheddin (2018) defined inflation rates refer to the change in the general level of prices in the economy over a given period of time. Inflation rate refer to the change whether up or down in the overall price levels of goods and services in an economy for a given period (Barakat, Elgazzar, \& Hanafy, 2016). Onundu (2016) conceptualized inflation rate as the changes in prices of goods and services directly and significantly affect the purchasing power of money as well as the cost of production in the manufacture of the same goods and services. The effects of inflation can be seen from two angles; the effect on the aggregate demand and on the cost of production. According to Shiblee (2009), inflation could be defined as a sustained increase in the general level of prices for goods, and services. Inflation rate is a rise in the general level of prices of goods and services in an economy over a period of time (Ariss, 2012). Thus, inflation is a persistent rise in the overall (or average) level of prices of all goods and services. Inflation occurs when prices of goods increase or when it needs more money to purchase few goods.

Moheddin (2018) stated that inflation rate scenario will exhibit a rising currency rate, as the purchasing power of the currency will increase as compared to other currencies (Moheddin, 2018). Generally, Moheddin (2018) the inflation rate is used to measure the price stability in the economy. Conceptually, the inflation rate can be divided into two sides, namely: demand side inflation (demand pull inflation) and supply side inflation (cost push inflation). Moheddin (2018) stated that the features of inflation rate is a quantitative measure of the rate at which the average price level of a basket of selected goods and services in an economy increases over some period of time. It is the rise in the general level of prices where a unit of currency effectively buys less than it did in prior periods. Egbunike and Okerekeoti (2018) stated that the advantages of inflation rate are; moderate inflation rate enables economic growth, moderate inflation rate allows adjustment of real wages, and moderate inflation rate allows adjustment of prices while disadvantages of inflation rate are; inflation rate create uncertainty, and lower investment, higher inflation rate often leads to lower growth and less stability, reduces international competitiveness, and inflation rate causes fall in value of savings.

\section{Infrastructural Facility}

Tuong, Binh, and Hoa (2019) defined infrastructural facility as the fundamental facilities and systems serving a country, city, or other area, including the services and facilities necessary for its economy to function. Infrastructural facility is composed of public and private physical improvements such as roads, railways, bridges, tunnels, water supply, sewers, electrical grids, and telecommunications (including Internet connectivity and broadband speeds). In general, Wan and Zhang (2018) defined infrastructural facility as the physical components 
of interrelated systems providing commodities and services essential to enable, sustain, or enhance societal living conditions. According to Tuong et al. (2019), there are two general types of ways to view infrastructural facility, hard or soft. Hard infrastructure refers to the physical networks necessary for the functioning of a modern industry. This includes roads, bridges, railways, etc. Soft infrastructure refers to all the institutions that maintain the economic, health, social, and cultural standards of a country. This includes educational programs, official statistics, parks and recreational facilities, law enforcement agencies, and emergency services.

Orji, Worika, and Umofia (2017) defines infrastructure as social (or soft-core), or physical (or hard-core) infrastructure. They contented was that soft-core infrastructure had to do with healthcare, governance, education, and accountability, as well as property rights, which are the driving forces of economic activities; whereas, hardcore infrastructure had to do with physical structures such as transport facilities, telecommunication facilities, power, water, and sewage, which they characterized as wheels of economic activities.. The definition of infrastructural services, as given by Faremo (2015) was that it is the structures and networks that frame and hold cities making it possible to carry out economic and social activities like power and water supply, telecommunications, as well as others. Ezeugbor and Obiekwe (2018) stated that the advantages of infrastructural facilities are; infrastructural facility enhance the economy to connect supply chains and efficiently move goods and services across borders. Infrastructure connects households across metropolitan areas to higher quality opportunities for employment, healthcare and education. Clean energy and public transit can reduce greenhouse gases.

\section{Interest Rate}

Moheddin (2018) defined interest rate as a price that equilibrates the desire to hold wealth in the form of cash with the available quantity of cash, and not a reward of savings. Murungi (2014) defined interest rate as the charge assessed for the use of money. It can also be seen as the payment made to owners of capital fund which they are ready to put at the disposal of others; thus, interest rate is like a price which bring into equilibrium the demand for resources to invest with the readiness to establish from present consumption. Barnor (2014) defined interest rate as the price a borrower pays for the use of money they borrow from a lender or fee paid on borrowed assets. Acha and Acha (2011) described interest rate as a price of money that reflects market information regarding expected change in the purchasing power of money or future inflation. While Acha and Acha (2011) further stated that when interest rates are increased, it costs more to borrow money. That means that businesses will not borrow as much in times of higher rates. When that happens, businesses spend less and hire less. In turn, this slows down an economy and if the economy is already slow, it can cause a recession.

\section{Exchange Rate}

Moheddin (2018) defined exchange rate as the price of a nation's currency in terms of another currency. An exchange rate thus has two components, the domestic currency and a foreign currency, and can be quoted either directly or indirectly. The price of one currency in terms of another is called the exchange rate. Yang and Zeng (2014) defined foreign exchange rate as the price of a currency in terms of another country currency. Osigwe and Uzonwanne (2015) defined exchange rate as how much or rate at which, foreign currency per unit can exchange to local or domestic currency. Obi, Oniore and Nnadi (2016) view exchange rate is the ratio between a unit of one currency and the amount of another currency for which that unit can be exchanged at a particular time. Central Bank of Nigeria (CBN) (2016) defined foreign exchange rate as the price for which a national currency is priced for another national currency.

Abdullahi, Fakunmoju, Abubakar and Giwa (2017) defined exchange rate as the price strength of one country's currency in relation to another country currency. This means that exchange rate deals with price strength of one currency against another currency which serves as an indicator for economic and stock market performance. Stemming from this definition, exchange rate of currency established the connection between domestic and foreign prices of goods and services and also serves as one of the indicators for manufacturing companies economic activities and economic performance (Abdullahi et al., 2017; Dewi, Soei, and Surjoko (2019) asserted in nowadays business environment, exchange rate plays an important role that affect profitability. The change in exchange rate has significant impact on business cost and profitability.

\section{Firm Performance}

Firm performance (FP) is fundamental to businesses as the key objective for business organisations is profit making (Olanipekun, Abioro, Akanni, Arulogun, \& Rabiu, 2015). Syafarudin (2016) defined firm performance as the outcome or accomplishment affected by the operations of the company in utilizing the resources owned. Jahanshahi, Rezaie, Nawaser, Ranjbar and Pitamber (2012) also describe firm performance as a result of the actual outcomefashioned by a company which is measured and compared with the expected results. Musyoka (2016) portray firm performance as having improvement over time as a result of the shared values in the company. According to Richard (2009), Firm's performance is the accomplishment of particular objectives measured on the 
basis of identified set standards. Also, Performance can be assessed through different dimensions (Agarwal, Erramilli \& Dev, cited in Bhatti, Awan \& Razaq 2013). Performance can be measured from the objective angle which involves financial and market-based measures, such as capacity utilisation, profitability and market share. Awino (2011) aver that for an organisation to be successful, it must have above average returns and identified performance drivers from the top to the lower levels of the organisation.

Sampath and Krishnamoorthy (2017) aver that organisational performance encompasses three specific areas of firm outcomes: financial performance (profits, return on assets, return on investments, return on equity); market performance (sales, market share, sales growth); and shareholders' return (total shareholder return, economic value added; dividend yield). Kirca, Jayachandran and Bearden (2005), they further argued that firm performance also entails the understanding and knowledge of the organisation regarding the needs and expectations of customers (customer satisfaction), competitors' goals and results (firm efficiency, competitive advantage) and regulatory requirements.

\section{Entrepreneurial Orientation, Economic Factors and Performance}

There are several past empirical studies on entrepreneurial orientation that show mixed empirical results by different scholars (Jenssen \& Nybakk, 2016; Jenssen \& Åsheim, 2017; Miller, 2014). Both economic factors and entrepreneurial orientation is an important factor for the competitive advantage and profitability of a firm (Miller, 2014). Olubiyi et al. (2019) found that Entrepreneurial Orientation (EO) has a positive effect on knowledge creation processes, which in turn positively influence firm performance. We think that the separate dimensions of EO - innovativeness, proactiveness and risk-taking - may play different roles in these relationships. We therefore think that studying the effects of the separate EO dimensions is important to understand how EO influences firm performance. As becomes clear from literature, and as has also been pointed out by Rezaei and Ortt (2017) recent research into EO has often merged the EO dimensions (innovativeness, proactiveness and risk-taking) into a single construct, analyzing their combined effect on firm performance.

Buli (2017) show the usefulness of viewing the firm's EO as a multidimensional construct. They show that all the EO dimensions may be present when a firm is entering a new market (the essential act of entrepreneurship), but that a successful new entry does not require all these EO dimensions in equal measure, and that some of these dimensions may play a more prominent role during a new market entry. Similarly, Dai et al. (2014) show that the dimensions in EO have differential roles in entering new international markets. Furthermore, the ability of a firm's EO dimensions to predict its success depends on several contingencies, for example, external variables such as cultural and industry characteristics and internal variables such as organizational structure (Wales, 2016). As further pointed out by Buli (2017), the multidimensionality of EO may result in different relationships between these EO dimensions and firm performance. This means that to fully understand the nature of EO-performance relationships, and to avoid misleading descriptive and normative theory building, we should consider the individual relationships between the different dimensions of EO and firm performance.

The study of Woschke, Haase, and Kratzer (2017) found that EO dimensions, all of which are found to have a positive effect on overall firm performance. Wambugu, Gichira and Wanjau (2016) revealed that entrepreneurial orientation had a positive and statistically significant influence on firm profitability, although the study looked at entrepreneurial orientation as a uni-dimensional construct in predicting firm performance. Anlesinya, Eshun, and Bonuedi (2015) found a significant positive effect of proactiveness and risk-taking on profitability but no relationship between entrepreneurial innovativeness and profitability of micro enterprises that operate in the retail sector in Ghana. Studies of Rubera and Kirca (2012) also observed that firm innovativeness affects financial position from the profitability context. Issah and Antwi (2017) and Mwangi and Wekesa (2017) found that economic factors had positive and significant effect on performance. Udu (2015) found that found that interest rate and unemployment rate were positive and significantly affect firm performance. Osamwonyi and Michael (2014) found that macroeconomic variables like Gross Domestic Product (GDP), interest and inflation rate positively affects firm performance. No studies within and outside Nigeria contexts have not empirically investigated the combine effect of combine effect of entrepreneurial orientation and economic factors on overall performance of selected quoted consumer goods companies.

Based on these aforementioned arguments that no empirical studies have examined combine effect of entrepreneurial orientation and economic factors on overall performance. Based on these aforementioned arguments that no empirical studies have examine combined effect of entrepreneurial orientation and economic factors on overall performance. Therefore, this study fills the empirical gap. 


\subsection{Conceptual Framework}

ENTREPRENEURIAL

ORIENTATION/ECONOMIC FACTORS

\section{PERFORMANCE}

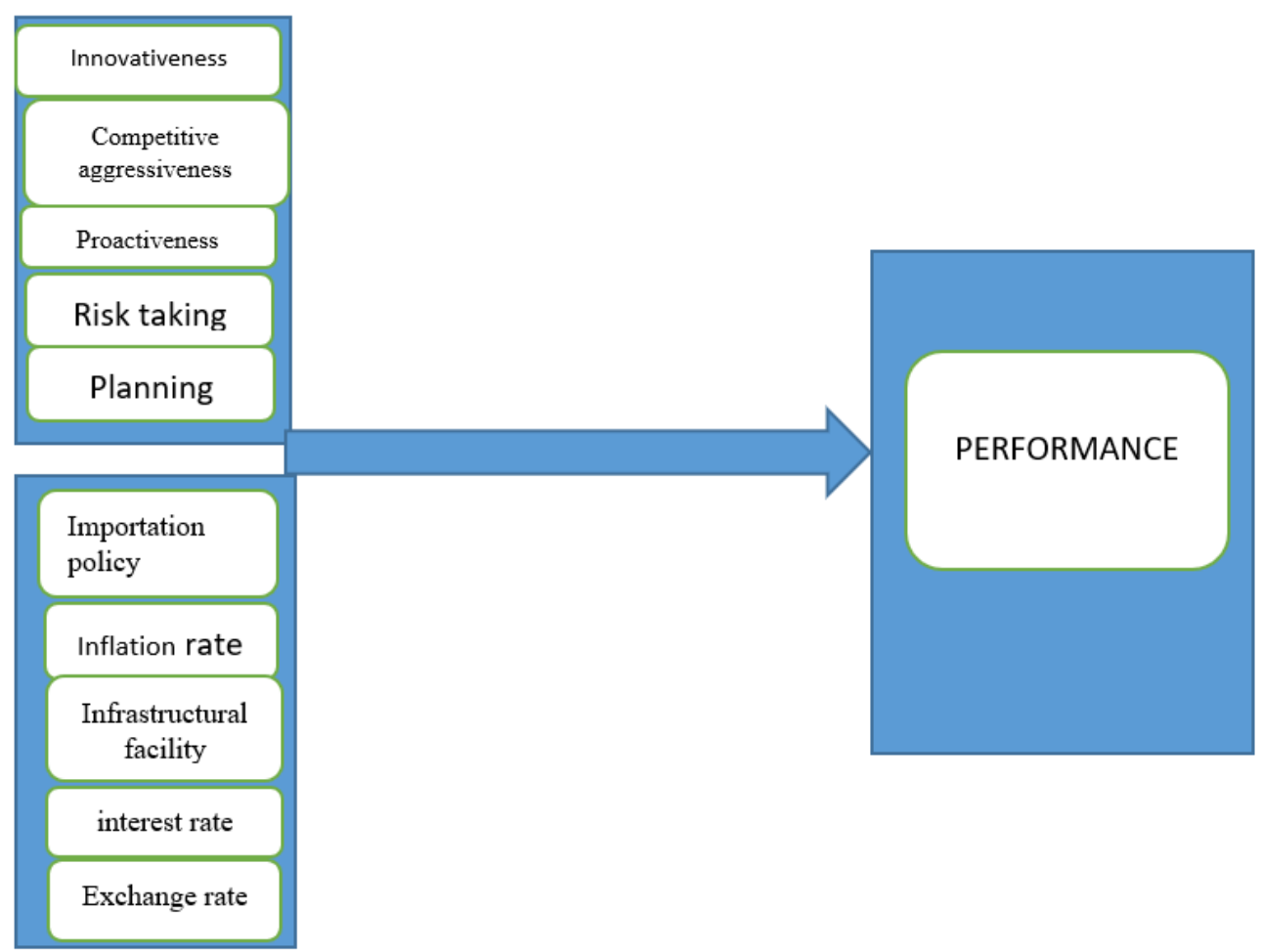

Researchers' conceptualisation (2021)

\subsection{Theoretical Framework}

This study adopted Resources-Based View (RBV) Theory and Entrepreneurship Innovation Theory (Barney, 1991; \& Schumpeter, 1949) as baseline theories for this study. These theories were selected to guide this study because their perspectives were tied to the focus of the study and the variables under investigation. The justification for these theories employed in this study were based on their theoretical explanation on the study variables; RBV states that the organizational resources and capabilities that were rare, valuable, non-substitutable, and imperfectly imitable form the basis for a firm's sustained competitive advantage and performance. Entrepreneurship Innovation Theory on its part, explains that innovation occurs when the entrepreneur introduces a new product or a new production system, opens a new market, discovers a new source of raw materials or introduces a new organization into the industry and in the process, enhances firm superior performance. Both Resource-based Theory and Entrepreneurship Innovation Theory capture the dynamics of the independent and dependent variables in this study.

\subsection{Methods}

\section{Research design}

This study adopts cross sectional survey research design which facilitated the use of a structured research instrument in obtaining data from the respondents for the study. Both top management and functional management staff were employed as population without considering other staff or lower cadre staff since decision makings towards entrepreneurial strategies are carried out by top and functional managers. Therefore, this study employed multi-stage sampling technique since the population of top management and functional Management staff is large. Data were analysed using descriptive and inferential (multiple regression analysis) statistics.

\section{Population and sample size of the Study}

The population for this research comprises twelve (12) quoted consumer goods manufacturing companies in Nigeria; Cadbury Nigeria Plc, Dangote Flour mills Plc, Dangote Sugar Refinery Plc, Flour Mill of Nigeria Plc, Guiness Nigeria Plc, Honeywell Flour mill Plc, Netsle Nigeria Plc, Nigerian Breweries Plc, PZ Cusson Nigeria Plc, 7-UP Bottling Company Plc, Unilever Nigeria Plc and Vitafoam Plc. These consumer goods manufacturing companies are selected because they are quoted on the Nigerian Stock Exchange (NSE) as at year 2020. The 
sample size for this study is determined by applying the Cochran (1997) formula: The sample of 494 was increased by 130 , or $30 \%$ of the total sample which equal 563 . This is as recommended by Zikmund (2000).

\section{Validity and Reliability of Research Instrument}

A pilot study was conducted to pre-test the questionnaire on 56 consumer goods manufacturing companies' staff (10\% of the sample size) which was randomly selected from the sample across other consumer goods manufacturing companies that were not part of consumer goods manufacturing companies used in this study. The consumer goods manufacturing companies were Multi-Trex Integrated Foods Plc, Nascon Allied Industries Plc, Nigerian Enamelware Plc, Union Dicon Salt Plc, and Champion Brew Plc and also eleven (11) questionnaires were distributed to each of the selected companies for pilot study. The total number of copies of the questionnaire retrieved from the sample was fifty-two (52). The responses were analyzed in order to determine the reliability of the research instrument. The result of the pilot study indicated that the research instrument was reliable, since the Cronbach's alpha of the scale for all the variables was greater than 0.70

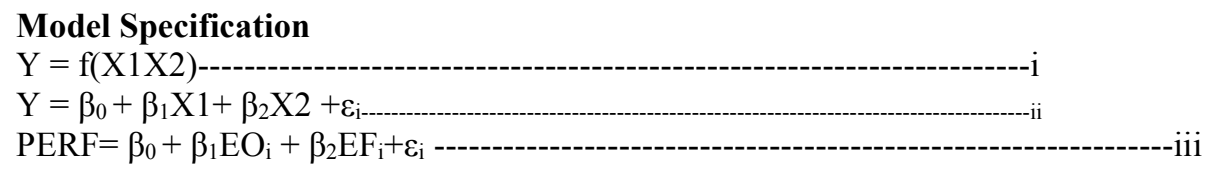

Where: $\mathrm{Y}=$ Performance (PERF)

$\mathrm{Y}=\left(\mathrm{y}_{1}, \mathrm{y}_{2}, \mathrm{y}_{3}, \mathrm{y}_{4}, \mathrm{y}_{5}\right)$

Where:

$\mathrm{y}_{1}=$ Market Share (MS)

$\mathrm{y}_{2}=$ Profitability $(\mathrm{PR})$

$\mathrm{y}_{3}=$ Sales Volume $(\mathrm{SV})$

$\mathrm{y}_{4}=$ Competitive Advantage (CA)

$\mathrm{y}_{5}=$ Productivity $(\mathrm{PRO})$;

$\mathrm{X} 1=$ Entrepreneurial Orientation (EO)

$\mathrm{X} 1=\left(\mathrm{x}_{1 \mathrm{a}}, \mathrm{x}_{1 \mathrm{~b}}, \mathrm{x}_{1 \mathrm{c}}, \mathrm{x}_{1 \mathrm{~d}}, \mathrm{x}_{1 \mathrm{e}}\right)$

And Where:

$\mathrm{x}_{1 \mathrm{a}}=$ Innovativeness (IN)

$\mathrm{x}_{1 \mathrm{~b}}=$ Competitive Aggressiveness (CAG)

$\mathrm{x}_{1 \mathrm{c}}=$ Proactiveness (PROA)

$\mathrm{x}_{1 \mathrm{~d}}=$ Risk-Taking $(\mathrm{RT})$

$\mathrm{x}_{1 \mathrm{e}}=$ Planning Flexibility $(\mathrm{PF})$

and $\mathrm{X} 2=$ Economic Factors $(\mathrm{EF})$

$\mathrm{X} 2=\left(\mathrm{x}_{2 \mathrm{a}}, \mathrm{x}_{2 \mathrm{~b}}, \mathrm{x}_{2 \mathrm{c}}, \mathrm{x}_{2 \mathrm{~d}}\right)$

$\mathrm{x}_{2 \mathrm{a}}=$ Importation Policy (IP)

$\mathrm{x}_{2 \mathrm{~b}}=$ Inflation Rate (IR)

$\mathrm{x}_{2 \mathrm{c}}=$ Infrastructural Facility (IF)

$\mathrm{x}_{2 \mathrm{~d}}=$ Interest Rate (INT)

$\mathrm{x}_{2 \mathrm{e}}=$ Exchange Rate (EXCHR)

$\beta_{0}=$ constant of the equation or constant term

$\beta_{1}-\beta_{5}=$ Parameters to be estimated

$\varepsilon_{\mathrm{i}}=$ error or stochastic term

\subsection{Results and interpretation}

Combined effect of entrepreneurial orientation and economic factors on overall performance of selected quoted consumer goods companies in Nigeria.

To test this hypothesis, multiple regression analysis was used. The independent variable was entrepreneurial orientation and economic factors while the dependent variable was performance. In the analysis, data for entrepreneurial orientation and economic factors were created by adding together responses of all the items under the various components to generate independent scores for each component. For performance, responses of all items the variable were added together to create index of prod performance. The index of performance (as dependent variable) is thereafter regress on scores (index) of entrepreneurial orientation and economic factors (as independent variables). The results of the analysis and parameter estimates obtained are presented in Table 1. 
Table 1: Summary Results of Multiple Regression Analysis of Performance on Entrepreneurial Orientation and Economic Factors of the selected quoted consumer goods companies in Nigeria.

\begin{tabular}{llllllll} 
Model & $\boldsymbol{B}$ & $\boldsymbol{T}$ & Sig. & $\boldsymbol{F ( 2 , 4 2 6 )}$ & $\mathbf{R}^{\mathbf{2}}$ & Adj. R $^{2}$ & F(Sig) \\
(Constant) & 6.612 & 2.404 & .017 & 1527.301 & 0.878 & 0.877 & 0.000 \\
Entrepreneurial Orientation & .420 & 7.288 & .000 & & & & \\
Economic Factors & .671 & 11.098 & .000 & & & & \\
\hline
\end{tabular}

a. Dependent Variable: Performance

b. Predictors: (Constant), Entrepreneurial Orientation and Economic Factors

Source: Researchers' Field Survey, 2021

Table 1 presented the multiple regression results for the combined effect of entrepreneurial orientation and economic factors on performance of the selected quoted consumer goods companies in Nigeria. The results revealed that entrepreneurial orientation $(\beta=0.420, \mathrm{t}=7.288, \mathrm{p}=0.000)$ and economic factor $(\beta=0.671, \mathrm{t}=$ $11.098, \mathrm{p}=0.000$ ) have positive and significant effects on performance of the selected quoted consumer goods companies in Nigeria. This implies that entrepreneurial orientation and economic factor are significant predictors of performance of selected quoted consumer goods companies in the study area.

The results further revealed that entrepreneurial orientation and economic factor explained $87.7 \%$ of the variation in performance of the selected quoted consumer goods companies $\left(A d j . R^{2}=0.877\right)$. However, the model did not explain $12.3 \%$ of the variation in performance of the selected quoted consumer goods companies in Nigeria, implying that there are other factors associated with performance of the selected quoted consumer goods companies that were not captured in the model. This concurs with Graham and Coffman (2012) that $R$-squared is always between 0 and 100\%: $0 \%$ indicates that the model explains none of the variability of the response data around its mean and $100 \%$ indicates that the model explains the variability of the response data around its mean. In general, the higher the $R$-squared, the better the model fits the data. The adjusted $R$ square was slightly lower than the $R$-square which implied that the regression model may be over fitted by including too many independent variables.

Also, the results of Analysis of Variance (ANOVA) for regression coefficients used to test the overall significance of regression model has the value of 1527.301 with $(2,426)$ degrees of freedom and p-value of 0.000 which was less than $0.05\left(F_{(2,426)}=1527.301, \mathrm{p}=0.000\right)$. This implies that the overall model was significant in predicting the performance of the selected quoted consumer goods companies in Nigeria. That is, performance is affected by entrepreneurial orientation and economic factor and the F value standing at 1527.301. The result shows that at least one of the entrepreneurial orientation and economic factors has a significant effect on the performance of the selected quoted consumer goods companies in Nigeria. In coming up with the final regression model to predict performance of the selected quoted consumer goods companies in Nigeria, the economic factors are statistically significant and were retained in the model. The multiple regression model from the results is thus expressed as:

$\mathrm{PER}=6.612+0.420 \mathrm{EO}+0.671 \mathrm{EF}$

Where:

$$
\begin{aligned}
& \text { PER }=\text { Performance } \\
& \mathrm{EO}=\text { Entrepreneurial Orientation } \\
& \mathrm{EF}=\text { Economic Factor }
\end{aligned}
$$

From the above regression equation above, it was revealed that holding entrepreneurial orientation and economic factors constant (at zero), performance of the selected quoted consumer goods companies in Nigeria will be 6.612. This implies that if entrepreneurial orientation and economic factors take on the values of zero (do not exist), there would be a 6.612 times level of repetition of the performance of the selected quoted consumer goods companies in Nigeria. The model shows that a unit change in entrepreneurial orientation and economic factors respectively will lead to 0.420 and 0.671 unit changes in performance of the selected quoted consumer goods companies in Nigeria. The results revealed that economic factors $(B=0.671, t=11.098 \mathrm{p}=0.000<0.05)$ was the most significant predictor (among entrepreneurial orientation and economic factor) on performance of the selected quoted consumer goods companies in Nigeria Since most of the regression coefficients were significant at 5\% significance level as indicated in Table 4.25, the null hypothesis was rejected. Therefore, the null hypothesis $\left(\mathrm{H}_{0}\right)$ which states that there is no significant combine effect of entrepreneurial orientation and economic factors on overall performance of selected quoted consumer goods companies in Nigeria is hereby rejected.

\section{Discussion of findings}

Result of multiple regression for Hypothesis indicated that the combined effect of entrepreneurial orientation and economic factors significantly influenced overall performance of selected quoted consumer goods companies in Nigeria $\left(A d j . R^{2}=0.877 ;\left(F_{(2,426)}=1527.301, \mathrm{p}=0.000\right)\right.$. There are several past empirical studies on entrepreneurial orientation that showed mixed empirical results by different scholars (Jenssen \& Nybakk, 2016; Jenssen \& Åsheim, 2017; Lages et al., 2016; Miller, 2014). Both economic factors and entrepreneurial orientation is an important 
factor for the competitive advantage and profitability of a firm (Miller, 2014). Olubiyi et al. (2019) found that Entrepreneurial Orientation (EO) has a positive effect on knowledge creation processes, which in turn positively influence firm performance. We think that the separate dimensions of EO - innovativeness, proactiveness and risktaking - may play different roles in these relationships. We therefore think that studying the effects of the separate EO dimensions is important to understand how EO influences firm performance. As becomes clear from literature, and as has also been pointed out by Rezaei and Ortt (2017) recent research into EO has often merged the EO dimensions (innovativeness, proactiveness and risk-taking) into a single construct, analyzing their combined effect on firm performance.

Wambugu, Gichira and Wanjau (2016) revealed that entrepreneurial orientation had a positive and statistically significant influence on firm profitability, although the study looked at entrepreneurial orientation as a uni-dimensional construct in predicting firm performance. Anlesinya, Eshun, and Bonuedi (2015) found a significant positive effect of proactiveness and risk-taking on profitability but no relationship between entrepreneurial innovativeness and profitability of micro enterprises that operate in the retail sector in Ghana. Studies of Rubera and Kirca (2012) also observed that firm innovativeness affects financial position from the profitability context. Issah and Antwi (2017) and Mwangi and Wekesa (2017) found that economic factors had positive and significant effect on performance. Udu (2015) found that found that interest rate and unemployment rate were positive and significantly affect firm performance. Osamwonyi and Michael (2014) found that macroeconomic variables like Gross Domestic Product (GDP), interest and inflation rate positively affects firm performance. Based on these empirical studies in support of the current study, there is a significant combined effect of entrepreneurial orientation and economic factors on overall performance of selected quoted consumer goods companies in Nigeria.

\section{Conclusion}

Considering the empirical findings, this study concluded that there was a significant combined effect of entrepreneurial orientation and economic factors on overall performance of selected quoted consumer goods companies in Nigeria.

\section{Recommendations}

The findings revealed a significant combined effect of entrepreneurial orientation and economic factors on overall performance of selected quoted consumer goods companies in Nigeria. Entrepreneurial orientation components and economic factors had significant combined effect on firm performance of quoted consumer goods companies in Nigeria. The study, thus, recommended that managers in the consumer goods manufacturing sector should practice entrepreneurial orientation ideology and be proactive enough in addressing economic factors for a further boost in their performances.

\subsection{Suggestion for further studies}

Future researchers could employ longitudinal survey research design to capture the dynamics of entrepreneurial orientation and economic factors and overall firm performance measures in the consumer goods industry. Future researchers could carry out a comparative study of other industries and consumer goods industry so as to observe and compare this study's findings with other industries and this will enable the researcher to compare results.

\section{References}

Abdullahi, I. B., Fakunmoju, S. K., Abubarkar, M. A., \& Giwa, K. O. (2017). Evaluating the causality effect of exchange rate and Nigeria balance of payment: An empirical analysis. Journal of Management and Social Sciences, 6(1), 34-52.

Acha, I. A., \& Acha, C. (2011). Interest rates in Nigeria: An analytical perspective. Research Journal of Finance and Accounting, 2(3), 71-81.

Adegbuyi, A. A., Oladele, P., Iyiola, O. O., Adegbuyi, O. A., Ogunnaike, O. O., Ibidunni, A. S., \& Fadeyi, O. (2018). Assessing the influence of entrepreneurial orientation on small and medium enterprises' performance. International Journal of Entrepreneurship, 22(4), 1-7

Adisa, M. K., Adeoye, A. O., \& Okunbanjo, O. I. (2016). The impact of entrepreneurship orientation on entrepreneurs compensation in Nigeria. International Journal of Economics, Business and Management Studies, 3(3), 102-116.

Adonisi, M. P. (2003). The relationship between corporate entrepreneurship, market orientation, organizational flexibility and job satisfaction. (Dissertation) University of Pretoria, Pretoria.

African Economic Outlook (AEO) (2020). https://www.afdb.org/en/knowledge/publications/african-economicoutlook

Aigboje, P. O. (2018). Competitive aggressiveness and organizational profitability of hotels in Port Harcourt, Nigeria. International Journal of Social Sciences and Management Research, 4(5), 37-44. 
Amiti, M., \& Konings, J. (2007). Trade liberalization, intermediate inputs, and productivity: Evidence from Indonesia. American Economic Review, 97(5), 1611-1638.

Anlesinya, A., Eshun, P., \& Bonuedi, A. A. (2015). Entrepreneurial orientation dimensions and profitability nexus: evidence from micro enterprises in the retail sector in a developing country. International Journal of Small Business and Entrepreneurship Research, 3(7), 79-87.

Ariss, R. T. (2012). Understanding Inflation and Revising National Price Data. Lebanese Economic Association, Beirut-Lebanon

Awino, Z. B. (2011). An Empirical Investigation of selected strategy variables on firms Performance: A Study of supply chain management in Large Private Manufacturing Firms in Kenya. Prime Journals, 1(1), 9-18.

Aziz, R. A., Mahmood, R., Tajudin, A., \& Abdullah, M. H. (2014). The relationship between entrepreneurial orientation and business performance of SMEs in Malaysia. International Journal of Management Excellence, 2(3), 221-226.

Bakari, S., \& Mabrouki, M. (2017). Impact of exports and imports on economic growth: new evidence from Panama. Journal of Smart Economic Growth, 2(1), 67-79.

Barakat, M. R., Elgazzar, S. H., \& Hanafy, K. M. (2016). Impact of macroeconomic variables on stock markets: Evidence from emerging markets. International Journal of Economics and Finance, 8(1), 195-207.

Barney, J. (1991). Looking inside for competitive advantage. Academy of $\quad$ Management Executive, 9 (4), 49-61.

Barnor, C. (2014). The effect of macroeconomic variables on stock market returns in Ghana (2000-2013). Walden Dissertations and Doctoral Studies.

Bass, B. M., \& Bass, R. (2008). The Bass handbook of leadership: Theory, research, and managerial applications $\left(4^{\text {th }}\right.$ ed. $)$. New York. Free Press.

Bhatti, H., Awan, M., \& Rasaq, Z. (2013). The key performance indicators (KPIs) and their impact on overall organisational performance. Springer Science.

Bran, A., \& Vaidis, D. (2019). Choose your own risks: measuring risk-taking through an interactive novel. Laboratoire de psychologie sociale, université Paris descartes, Paris, France.

Buli, B. M. (2017). Entrepreneurial orientation, market orientation and performance of SMEs in the manufacturing industry: Evidence from Ethiopian enterprises. Management Research Review, 3(2), 4-18.

Dai, L., Maksimov, V., Gilbert, B. A., \& Fernhaber, S. A. (2014). Entrepreneurial orientation and international scope: The differential roles of innovativeness, proactiveness, and risk-taking. Journal of Business Venturing, 29(4), 511-524.

Davis, E. P. (2012). The crisis and the kingdom. Wipf and stock, Eugene, Oregon.

Deloitte Report (2020). https://www2.deloitte.com/by/en/pages/consumer-business/solutions/food-beverage.html

Dewi, V. I., Tan Lian Soei, C., \& Surjoko, F. O. (2019). The Impact of Macroeconomic Factors on Firms Profitability (Evidence from fast moving consumer good firms listed on Indonesian stock exchange). Academy of Accounting and Financial Studies Journal, 23 5(1), 23-39.

Edwards, S. (2002). The great exchange rate debate after Argentina. The North American Journal of Economics and Finance, 13(3), 237-252.

Egbunike, C. F., \& Okerekeoti, C. U. (2018).Macroeconomic factors, firm characteristics and financial performance. Asian Journal of Accounting Research, 4(16), 55-62.

Eggers, F., Kraus, S., Hughes, M., Laraway, S., \& Snycerski, S. (2013). Implications of customer and entrepreneurial orientations for SME growth. Management Decision, 4(8), 12-25.

Ejdys, J. (2016). Entrepreneurial orientation vs. innovativeness of small and medium size enterprises. Journal of Engineering, Project, and Production Management, 6(1), 13-24.

Etim, J. J., Adabu, M.U., \& Ogar, C.A. (2017). Influence of entrepreneurial orientation as survival strategy for small and medium enterprises: The Nigeria experience. International Journal of Economics, Commerce and Management, 2(2), 502-518

Ezeugbor, E., \& Obiekwe, K. K. (2018). Adequacy of infrastructural facilities required for the implementation of Nigeria education management information system policy in Anambra state. Journal of the Nigerian Academy of Educationl, 14(2), 13.

Faremo, G. (2015). Build resilient infrastructure, promote inclusive and sustainable industrialization and foster innovation. UN Chronicle, 51(4), 21-22.

Fink, S., \& Benz, F. (2019). Flexibility planning in global inbound logistics. Procedia CIRP, 79, 415-420.

Fosu, O. G., Bondzie, E. A., \& Okyere, A. G. (2014). Does foreign direct investment really affect Ghana's economic growth?. International Journal of Academic Research and Management Science, 3(1), 47-59.

Goodwin, A. (2012). EMU Market Dynamics: Labour Market Flexibility in Europe. CBI Organisation, Great Britain.

Graham, S., Mckeown, D., Kiuhara, S., \& Harris, K. R. (2012). A meta-analysis of writing instruction for students in the elementary grades. Journal of educational psychology, 104, 879-896. 
Hamid, N. A., \& Tasmin, R. (2013). The relationship of business innovation capabilities and technology innovation capabilities on SME organization performance: a conceptual framework. Economics and business, 4(4), 6578.

Hernández-Sánchez, B. R., Cardella, G. M., \& Sánchez-García, J. C. (2020). Psychological Factors that Lessen the Impact of COVID-19 on the Self-Employment Intention of Business Administration and Economics' Students from Latin America. International Journal of Environmental Research and Public Health, 17(15), 52-93.

Issah, M., \& Antwi, S. (2017). Role of macroeconomic variables on firms' performance: Evidence from the UK. Cogent Economics \& Finance, 5(1), 1-41.

Jahanshahi, A. A., Rezaei, M., Nawaser, K., Ranjbar, V., \& Pitamber, B. K. (2012). Analyzing the effects of electronic commerce on organizational performance: Evidence from small and medium enterprises. African Journal of Business Management, 6(22), 6486-6496.

Javad, M. Y., Alireza, K., \& Yaghoob, M. (2015). Organizational Entrepreneurship and its Impact on the Performance of Governmental Organizations in the City of Mashhad. Procedia-Social and Behavioral Sciences, $169(20), 75-87$.

Jenssen, J. I., \& Åsheim, K. (2017). Organizational innovation promoters and performance effects in small, knowledge-intensive firms. International Journal of Innovation and Entrepreneurship, 11 (1), 19-27.

Jenssen, J. I., \& Nybakk, E. (2016). Inter-organizational innovation promoters in small, knowledge-intensive firms. International Journal of Innovation Management, 13(3), 441- 466.

Jonsson, D. (2007). Flexibility, stability and related con-cepts. In Furlker, B., Híkansson, K. \& Karlsson, J. (Eds.), Flexibility and stability in working life. Hampshire: Palgrave Macmillan.

Kartikasari, D. (2017). The Effect of Export, Import and Investment to Economic Growth of Riau Island Indonesia. International Journal of Economics and Financial Issues, 7(4), 663-667.

Keh, H. T., Nguyen, T. T. M., \& Ng, H. P. (2007). The effects of entrepreneurial orientation and marketing information on the performance of SMEs. Journal of business venturing, 22(4), 592-611.

Ketchen, D., \& Short, J. (2012). Strategic management: Evaluation and execution. New York: Creative Common.

Kirca, A. H., Jayachandran, S., \& Bearden, W. O. (2005). Market orientation: A meta-analytic review and assessment of its antecedents and impact on performance. Journal of marketing, 69(2), 24-41.

Kiveu, M. N., Namusonge, M., \& Muathe, S. (2019). Effect of innovation on firm competitiveness: the case of manufacturing SMEs in Nairobi County, Kenya. International Journal of Business Innovation and Research, 18(3), 307-327.

Kozjek, T., \& Ferjan, M. (2015). Organisational flexibility, employee security, and organisational efficiency- a case of Slovenian public and private sector organisations. Organizacija, 48. DOI: 10.1515/Oga.

Kropp, F., Lindsay, N., \& Shoham, A. (2008). Entrepreneurial orientation and international business venture startup. International journal of entrepreneurial behaviour and research, 14(2),102-117.

Kurgat, E. K., Weru, I., Wata, D. (2020). Proactive risk assessment of vincristine use process in a teaching and referral hospital in Kenya and the implications. Journal of Oncology Pharmacy Practice, 26(3), 666-679. Kwon, S. J., Ryu, D., \& Park, E. (2018). The influence of entrepreneurs' strategic agility and dynamic capability on the opportunity pursuit process of new ventures: Evidence from South Korea. Academy of Strategic Management Journal, 17(1), 1-17.

Li, Y. H., Huang, J. W., \& Tsai, M.T. (2010). Entrepreneurial orientation and firm performance: The role of knowledge creation process. Industrial Marketing Management, 38(4), 440-449.

Lin, C. Y., \& Chen, M. Y. (2007). Does innovation lead to performance? An empirical study of SMEs in Taiwan. Management research news, 30 (2), 115-132.

Linyiru, B. M., \& Ketyenya, R. P. (2017). Influence of competitive aggressiveness on performance of state corporations in Kenya. International Journal of Entrepreneurship, 2(1), 1-14.

Manufacturing Association of Nigeria

(MAN) (2019).https://www.manufacturersnigeria.org/ManInDailyNigerianNews

Miller, D. (2016). Response to" research on the dark side of personality traits in entrepreneurship: observations from an organizational behavior perspective. Entrepreneurship: Theory and Practice, 40(1), 19-25.

Mkalama, B. W., Ndemo, B. E., \& Maalu, J. K. (2018). The antecedents of innovativeness in small and medium manufacturing enterprises in Kenya: A critical review of literature. African Journal of Business Management, 12(17), 527-535.

Moheddin, A. A. (2018). Macroeconomic factors and exchange rates in Kenya (Doctoral dissertation, United States International University-Africa).

Mohsen, A. (2013). Study the Effect of Trade Policies on Exports and Imports in Iran. World Applied Sciences Journal, 21(12), 1748-1751.

Muhonen, S. (2017). The profitability of competitive aggressiveness: The moderating effect of industry-related and organizational factors. A thesis submitted at Aalto University School of Business Department of 
Marketing. Mukutu, J. K. (2017). Impact of corporate entrepreneurship strategy on growth of business organisations: A case of safaricomlimited. a research project proposal submitted to the chandaria school of business in partial fulfillment of the requirement for the Degree of Masters in Business Administration (MBA).

Murungi, D. U. (2014). Relationship between macroeconomic variables and financial performance of insurance companies in Kenya (Doctoral Dissertation, University of Nairobi).

Musyoka, D. (2016). The effect of use of financial statements in making lending decisions on level of nonperforming loans among commercial banks in Kenya (Doctoral dissertation, University of Nairobi).

Mwangi, E., \& Wekesa, S. (2017). Influence of economic factors on organizational performance of airlines: A case study Kenya airways ltd. IOSR Journal of Humanities and Social Science, 22(5), 8-14.

Mwangi, M. M. \& Ngugi, K. (2014). Influence of Entrepreneurial Orientation on Growth of Micro and Small Enterprises In Kerugoya, Kenya. European Journal of Business Management, 1(11), 417-438.

Mwangi, S. M., \& Namusonge, M. J. (2014). Influence of innovation on small and medium Enterprise (SME) growth-A case of garment manufacturing Industries in Nakuru County. International Journal for Innovation Education and Research, 2(6), 101-107.

Nyaruirumugure, M., Simiyu, J. M. \& Bunde, A. O. (2017). Analysis of macroeconomic determinants of economic growth in Kenya. The international journal of humanities and social studies, 5 (9).

Obeng-Krampah, D. K. (2018). The Impact of Macroeconomic Factors on Firm Performance (Doctoral dissertation, University of Ghana).

Obi, K. O., Oniore, J. O., \& Nnadi, K. U. (2016). The impact of exchange rate regimes on economic growth in Nigeria. Journal of Economics and Sustainable Development, 7(12), 115-127.

Ojeleye, Y. C., Opusunju, M. I., \&Abdullahi, A. I. (2020). Globalisation and performance of manufacturing sector in Nigeria. Journal of Accounting and Management, 3(1), 12-18.

Okangi, F. P. (2019). The impacts of entrepreneurial orientation on the profitability growth of construction firms in Tanzania. Journal of Global Entrepreneurship Research, 9(1), 14-31.

Okunbanjo, I. O., Adewale, O. M., \& Akinsulire, O. H. (2016). Effect of entrepreneurs' character on SMEs performance in Lagos State, Nigeria. Journal of Management and Science, 7(3), 17-26.

Olanipekun, W. D., Abioro, M. A., Akanni, L. F., Arulogun, O. O., \& Rabiu, R. O. (2015). Impact of Strategic Management on Competitive Advantage and Organisational Performance-Evidence from Nigerian Bottling Company. Journal of Policy and development Studies, 289(1850), 1-14.

Oloyede, O., \& Essi, D. I. (2017). The effect of exchange rate on imports and exports in Nigeria from January 1996 to June 2015. IIARD International Journal of Economics and Business Management, 3(2), 66-77.

Olubiyi, T. O., Egwakhe, A. J., Amos, B., \& Ajayi, A. A. (2019). Entrepreneurial Orientation and Firm Profitability: Evidence from Lagos State Nigeria. Entrepreneurial Orientation and Firm Profitability: Evidence from Lagos State Nigeria, 21(6), 42-54.

Omisakin, O., Nakhid, C., Littrell, R., \& Verbitsky, J. (2016). Entrepreneurial orientation among migrants and small and medium enterprises. International journal of business and management review, 3(4), 7-22.

Onundu, M. D. (2016). The effect of inflation on stock price and returns volatility for securities listed at the Nairobi securities exchange (Doctoral dissertation, University of Nairobi).

Organisation for Economic Co-operation and Development (2019).https://www.oecd.org/development/development-co-operation-report-20747721.htm

Orji, K., Worika, I. L., \& Umofia, N. (2017). The Impact of Infrastructural Development on Nigeria's Industrial Sector. African Research Review, 11(3), 23-30.

Osamwonyi, I. O., \& Michael, C. I. (2014).The impact of macroeconomic variables on the profitability of listed commercial banks in Nigeria. European Journal of Accounting Auditing and Finance Research, 2(10), 85-95

Osigwe, A. C., \& Uzonwanne, M. C. (2015). Causal relationship among foreign reserves, Exchange rate and foreign direct investment: Evidence from Nigeria. International Journal of Economics and Financial Issues, 5(4), 45-59.

Reijonen, H., Tammi, T., \& Saastamoinen, J. (2016). SMEs and public sector procurement: Does entrepreneurial orientation make a difference?. International Small Business Journal, 34(4), 468-486.

Rezaei, J., \& Ortt, R. (2018). Entrepreneurial orientation and firm performance: the mediating role of functional performances. Management Research Review, 3(4), 14-22.

Richard (2009). Measuring Organisational Performance: Towards Methodological Best Practice, Journal of Management.

Rubera, G., \& Kirca, A. H. (2012). Firm innovativeness and its performance outcomes: A meta-analytic review and theoretical integration. Journal of Marketing, 76(3), 130-147.

Sampath, G., \& Krishnamoorthy, B. (2017). Is strategic agility the new Holy Grail? Exploring the strategic agility construct. International Journal of Business Excellence, 13(2), 160-180.

Schillo, R. S. (2011). Entrepreneurial orientation and company performance: can the academic literature guide managers?. Technology Innovation Management Review, 1(2), 43-58. 
Schumpeter, J. A. (1949). Economic theory and entrepreneurial history in Wohl, R.R. (ed.). Change and the entrepreneur: postulates and the patterns for entrepreneurial history and research centre in entrepreneurial history, Cambridge, Massachussetts: Harvard University Press.

Sheu, J. B. (2017). Buyer behavior in quality - dominated multi - sourcing recyclable - material procurement of green supply chains. Production and Operations Management, 25(3), 477-497.

Shiblee, L. S. (2009). The impact of inflation, GDP, unemployment, and money supply on stock prices. GDP, unemployment, and money supply on stock prices. Retrieved from https://ssrn.com/abstract=1529254

Susilo, A. (2008). Buku Pintar Ekspor-Impor (Manajemen Tata Laksana \& Transportasi Internasional). Jakarta: Trans Media.

Syafarudin, A. (2016). Strategy of leadership and innovation in improving company performance against competitive advantage: A case study of PT. Pegadaian (Ltd) Indonesia. International Journal of Economics, Commerce and Management, 4(6), 471-482.

Tuong, V., Binh, T., \& Hoa, N. D. (2019). Impact of transport infrastructure on firm performance: Case study of Cuu long delta area, Vietnam. Problems and Perspectives in Management, 17(2), 51-62.

Udu, A. A. (2015). Apprenticeship orientation and performance of microbusinesses in Ebonyi state, Nigeria. International Journal of Business and Management Review, 3(5), 30-40.

Wachsen, E., \& Blind, K. (2011). More flexibility for more innovation? Working Paper 115, University of Amsterdam. Retrieved 29. 08. 2020 from: http://www.uvaaias.net/uploaded_files/publications/WP115Wachsen,Blind.pdf

Wales, W. J. (2016). Entrepreneurial orientation: A review and synthesis of promising research directions. International Small Business Journal, 34(1), 3-15.

Wambugu, A. W., Gichira, R., Wanjau, K. N.,\& Mungatu, J. (2015).The relationship between risk taking and performance of small and medium agro processing enterprises in Kenya. International Journal of Economics, Commerce and Management, 3(12), 441-455.

Wan, G., \& Zhang, Y. (2018). The direct and indirect effects of infrastructure on firm productivity: Evidence from Chinese manufacturing. China Economic Review, 49, 143-153.

Wiklund, J., \& Shepherd, D. (2005). Entrepreneurial orientation and small business performance: a configurational approach. Journal of Business Venturing, 20(1), 71-91.

Woschke, T., Haase, H., \& Kratzer, J. (2017). Resource scarcity in SMEs: effects on incremental and radical innovations. Management Research Review, 4(5), 87.

Yang, B. Z., \& Zeng, T. (2014). A Note on the Real Currency Exchange Rate: Definitions and Implications. Journal of International Business and Economics, 2(4), 45-55.

Yang, C., \& Liu, H. M. (2012). Boosting firm performance via enterprise agility and network structure. Management Decision, 50(6), 1022-1044. 